\title{
Correlation of Personal Hygiene Knowledge, Attitude and Practices among School Children in Sumedang, Indonesia
}

\author{
Briska Sudjana, ${ }^{1}$ Irvan Afriandi, ${ }^{2}$ Julistio T. B. Djais ${ }^{3}$ \\ ${ }^{1}$ Faculty of Medicine Universitas Padjadjaran, ${ }^{2}$ Department of Public Health Faculty of \\ Medicine Universitas Padjadjaran, ${ }^{3}$ Department of Child Health Faculty of Medicine Universitas \\ Padjadjaran/Dr. Hasan Sadikin General Hospital Bandung,
}

\begin{abstract}
Background: School-age children make up the largest proportion of Indonesian youth population. One of the ways to maintain children's health is by making personal hygiene as a habit. The aim of this study was to analyze the correlation of personal hygiene knowledge, attitude and practices among school children.

Methods: A cross-sectional analytic study, was carried out to 123 sixth graders at five elementary schools in Jatinangor, Sumedang, Indonesia, who were selected using a multi-stage sampling technique. This study was carried out in October 2013. A validated questionnaire was used to collect data of demographic characteristics of the subjects, knowledge, attitude and practice related to personal hygiene.The collected data was analyzed using Rank Spearman correlation with the level of significance was set at $\mathrm{p}<0.05$.

Results: This study revealed that there was a significant correlation between knowledge and personal hygiene practice $(\mathrm{p}=0.016<0.05$ and $\mathrm{rs}=0.358)$ and attitudes and personal hygiene practice $(\mathrm{p}=0.027<0.05$ and rs=0.267).

Conclusions: There is correlation of personal hygiene knowledge, attitudes and practices, however, the correlation is weak. [AMJ.2016;3(4):549-55]
\end{abstract}

Keywords: Attitude, elementary students, knowledge, personal hygiene, practice

\section{Introduction}

School-age children make up the largest proportion of Indonesian youth population. The population Census in 2010 indicated that Indonesia had 237.6 million people. Out of that number, around 81.4 million $(34.26 \%)$ are children under 18 years of age. In 2011, people in elementary school education age group of 7-12 years old were recorded to be 27.3 million. ${ }^{1}$ Considering the large number of school children, their health should obviously be a concern. The result of a preliminary research conducted in 2010 to 51 respondents comprising students of Pasirlangu 01 Elementary School in Cisarua, West Java, ${ }^{2}$ regarding the factors that promote the prevalence of ascariasis indicated that $50.98 \%$ involved personal hygiene.

One of the ways to maintain children's health is by making personal hygiene a habit. Personal hygiene is the basic concept of cleaning, grooming and it is the first step to good health. ${ }^{3,4}$ It refers to practices that help to maintain health and prevent the spread of diseases, involves regular bathing, washing the hands, cutting the nails, changing the clothes, washing the hair and brushing the teeth., ${ }^{5,6}$ The process of behavior consists of knowledge, attitude and practice. The practice of personal hygiene is influenced by a number of factors which include, among others, the person's knowledge and attitude. This study was intended to analyze whether there was correlation of personal hygiene knowledge,attitude and practice among school children. ${ }^{\text {? }}$

\section{Methods}

This study was a cross sectional analytic study, conducted in October 2013 among sixth grade of five Elementary Schools in Jatinangor, Sumedang, Indonesia. The data were collected from 123 students using a multi-stage sampling technique. In the first stage, five public Elementary Schools were selected from the list of twenty-eight schools in Jatinangor by

Correspondence: Briska Sudjana, Faculty of Medicine, Universitas Padjadjaran, Jalan Raya Bandung-Sumedang Km.21, Jatinangor, Sumedang, Indonesia, Phone: +6281312110611 Email: briskasudjana@gmail.com 
simple random sampling. In the second stage, based on the class register, the proportional random sampling was used to select children from each class in the five selected schools with the following inclusion criteria: sixth grades students of Elementary School in Jatinangor and willing to follow the studyprocedure. On the other hand, the exclusion criterion was that the subject was absent at the time the collecting of data was conducted. A validated questionnaire was used as an instrument to obtain demographic characteristics (gender, age), knowledge, attitude and practice toward personal hygiene that included regular bathing, washing the hands, cutting the nails, changing the clothes, washing the hair and brushing the teeth. The variables were scored for knowledge, under the requirement for each value of a correct answer was scored 2 (two) and scored 1 (one) for an incorrect answer; attitude, under the requirement for each "strongly agree" statement was scored 4 (four), for each "agree" statement was scored 3 (three), for each "disagree" statement was scored 2 (two), and was scored 1 (one) for each "strongly disagree" statement; practice, under the requirement for each value consistent answer scored 2 (two) and scored 1 (one) for inconsistent answer. A computer was used
Table 1 Respondents' Characteristics

\begin{tabular}{lcc}
\hline Variable & Frequency & $\mathbf{\%}$ \\
\hline Age (years old) & & \\
10 & 4 & 3.25 \\
11 & 84 & 68.29 \\
12 & 35 & 28.46 \\
Gender & & \\
Male & 71 & 57.72 \\
Female & 52 & 42.28 \\
\hline
\end{tabular}

to input and process the collected data. Data were analyzed by Rank Spearman correlation with the level of significance was set at $p<0.05$.

This study was approved by the Health Research Ethics Committee of Universitas Padjadjaran, Bandung, and the informed consent was obtained from the Local Development Planning Agency of Sumedang District, Sumedang District Department of Education, and school authorities.

\section{Results}

The majority of children (68.29\%) were in

Table 2 Personal Hygiene Knowledge

\begin{tabular}{|c|c|c|c|}
\hline Question & Category & n (123) & $\%$ \\
\hline \multirow{2}{*}{ Personal hygiene is self-treatment to maintain good health } & True & 120 & 97.5 \\
\hline & False & 3 & 2.5 \\
\hline \multirow[t]{2}{*}{ The purpose of maintaining personal hygiene to be healthy } & True & 115 & 93.4 \\
\hline & False & 8 & 6.6 \\
\hline \multirow{2}{*}{$\begin{array}{l}\text { Personal hygiene includes brushing teeth and cleaning the space } \\
\text { between the teeth }\end{array}$} & True & 114 & 92.6 \\
\hline & False & 9 & 7.4 \\
\hline \multirow[t]{2}{*}{ The best time to visit a dentist is once every six months } & True & 84 & 68 \\
\hline & False & 39 & 32 \\
\hline \multirow[t]{2}{*}{ The first thing to do before eating is washing hands with soap } & True & 120 & 97.5 \\
\hline & False & 3 & 2.5 \\
\hline \multirow[t]{2}{*}{ Long and dirty nails show lack of attention to personal hygiene } & True & 108 & 87.7 \\
\hline & False & 15 & 12.3 \\
\hline \multirow[t]{2}{*}{ Washing hands with soap can kill germs } & True & 119 & 96.7 \\
\hline & False & 4 & 3.3 \\
\hline \multirow[t]{2}{*}{ Long and dirty nails may contain worm eggs } & True & 114 & 92.6 \\
\hline & False & 9 & 7.4 \\
\hline \multirow[t]{2}{*}{ Washing hair may be done using common soap } & True & 114 & 92.6 \\
\hline & False & 9 & 7.4 \\
\hline
\end{tabular}


Briska Sudjana, Irvan Afriandi, Julistio T. B. Djais: Correlation of Personal Hygiene Knowledge, Attitude and 551 Practices among School Children in Sumedang, Indonesia

Table 3 Attitudes toward Personal Hygiene

\begin{tabular}{|c|c|c|c|}
\hline Question & Category & n (123) & $\%$ \\
\hline \multirow[t]{4}{*}{ Information on personal hygiene is very important } & Strongly agree & 97 & 78.9 \\
\hline & Agree & 25 & 20.3 \\
\hline & Disagree & 1 & 0.8 \\
\hline & Strongly disagree & 0 & 0 \\
\hline \multirow{4}{*}{$\begin{array}{l}\text { Although it is recommended to visit a dentist once every six } \\
\text { months, I'm too lazy to do it }\end{array}$} & Strongly agree & 3 & 2.4 \\
\hline & Agree & 10 & 8.1 \\
\hline & Disagree & 60 & 48.8 \\
\hline & Strongly disagree & 50 & 40.7 \\
\hline \multirow[t]{4}{*}{ Washing hands with soap is necessary } & Strongly agree & 82 & 66.7 \\
\hline & Agree & 35 & 28.5 \\
\hline & Disagree & 3 & 2.4 \\
\hline & Strongly disagree & 3 & 2.4 \\
\hline \multirow[t]{4}{*}{ Washing hands before eating is inconvenient } & Strongly agree & 5 & 4.1 \\
\hline & Agree & 7 & 5.7 \\
\hline & Disagree & 60 & 48.8 \\
\hline & Strongly disagree & 51 & 41.4 \\
\hline \multirow[t]{4}{*}{ I tend to be too lazy to cut my nails every week } & Strongly agree & 4 & 3.3 \\
\hline & Agree & 10 & 8.1 \\
\hline & Disagree & 49 & 39.8 \\
\hline & Strongly disagree & 60 & 48.8 \\
\hline \multirow{4}{*}{$\begin{array}{l}\text { I'm worried that my hair will fall if I wash it once every two } \\
\text { days }\end{array}$} & Strongly agree & 12 & 9.8 \\
\hline & Agree & 34 & 27.6 \\
\hline & Disagree & 59 & 48 \\
\hline & Strongly disagree & 18 & 14.6 \\
\hline \multirow[t]{4}{*}{ I find it inconvenient to change clothes } & Strongly agree & 4 & 3.2 \\
\hline & Agree & 12 & 9.8 \\
\hline & Disagree & 61 & 49.6 \\
\hline & Strongly disagree & 46 & 37.4 \\
\hline \multirow[t]{4}{*}{ Taking a bath twice a day is too much } & Strongly agree & 14 & 11.4 \\
\hline & Agree & 14 & 11.4 \\
\hline & Disagree & 56 & 45.5 \\
\hline & Strongly disagree & 39 & 31.7 \\
\hline
\end{tabular}

the 11-year-old age group, while $28.46 \%$ and $3.25 \%$ of them were in the 12 and 10 -year-old age group, respectively. Based on the gender, over half of the students were male (Table 1).

Questions regarding personal hygiene knowledge consisted of 9 questions. Most of the students had good knowledge of personal hygiene. Most of them answered the 9 questions correctly. For example, it revealed that $97.5 \%$ of the students understoond that the first thing to do before eating was washing their hands with soap. Regarding visiting a dentist every 6 months, only $68.0 \%$ of them answered this question correctly (Table 2).

Furthermore, there were 8 questions about attitude toward personal hygiene. The highest percentage of "strongly agree" answered by the students was the question about "information on personal hygiene is very important" (78.9\%), followed by the 
Table 4 Personal Hygiene Practices

\begin{tabular}{|c|c|c|c|}
\hline Question & Category & n (123) & $\%$ \\
\hline \multirow{2}{*}{ Visit a dentist in the past year } & Consistent & 76 & 61.8 \\
\hline & Inconsistent & 47 & 38.2 \\
\hline \multirow[t]{2}{*}{ Brush teeth after eating } & Consistent & 99 & 80.5 \\
\hline & Inconsistent & 24 & 19.5 \\
\hline \multirow[t]{2}{*}{ Brush teeth before bed } & Consistent & 101 & 82.1 \\
\hline & Inconsistent & 22 & 17.9 \\
\hline \multirow[t]{2}{*}{ Brush teeth after last meal } & Consistent & 88 & 71.5 \\
\hline & Inconsistent & 35 & 28.5 \\
\hline \multirow[t]{2}{*}{ Always use soap when washing hands } & Consistent & 116 & 94.3 \\
\hline & Inconsistent & 7 & 5.7 \\
\hline \multirow[t]{2}{*}{ Habit after going home from school } & Consistent & 103 & 83.7 \\
\hline & Inconsistent & 20 & 16.3 \\
\hline \multirow[t]{2}{*}{ Daily bath frequency } & Consistent & 111 & 90.2 \\
\hline & Inconsistent & 12 & 9.8 \\
\hline \multirow[t]{2}{*}{ Hair-washing frequency } & Consistent & 51 & 41.5 \\
\hline & Inconsistent & 72 & 58.5 \\
\hline \multirow[t]{2}{*}{ Way of washing hair } & Consistent & 116 & 94.3 \\
\hline & Inconsistent & 7 & 5.7 \\
\hline \multirow[t]{2}{*}{ Share the same towel with father/mother/brother/sister } & Consistent & 90 & 73.2 \\
\hline & Inconsistent & 33 & 26.8 \\
\hline \multirow{2}{*}{$\begin{array}{l}\text { Ask friends to practice personal hygiene (such as washing hands, } \\
\text { taking a bath, brushing teeth, etc.) }\end{array}$} & Consistent & 95 & 77.2 \\
\hline & Inconsistent & 28 & 22.8 \\
\hline
\end{tabular}

question about "washing hands with soap is necessary" (66.7\%). The rest of the questions were answered "strongly agree" or "strongly disagree" were below $50 \%$ (Table 3 ).

Moreover, $90.2 \%$ of the students confessed they took a bath twice a day, but only $41.5 \%$ of them claimed to wash their hair according to the recommended frequency (Table 4).

The correlation between knowledge and personal hygiene practice was indicated by Rank Spearman correlation coefficient (rs) of $0.358(\mathrm{p}=0.016)$. Meanwhile, the correlation between attitude and personal hygiene practice was indicated by rs of $0.267(p=0.027)$ (Figure 1 and 2).

\section{Discussion}

This study discovered that the majority of students had the knowledge that the first thing to do before eating was washing their hands with soap. This result was similar to a study conducted on Elementary School students in
Pekalongan, Central Java ${ }^{8}$, which also indicated that the majority of students washed their hands with soap before eating (94.0\%).

Knowledge is a very important domain that determines a person's actions. Research shows that actions based on knowledge last longer than those not based on knowledge. This study result is also supported by the theory of Green, stating that knowledge is a predisposing factor in shaping behavior. A person's behavior regarding health matters is determined by his/her knowledge. It is important that health behavior is related to the process of shaping behavioral changes because these changes are the objectives of health education or health counseling to support other health programs. Additionally, an action or behavior is an observable response against active stimuli. After the stimulus of health objects is known, a person may assess or give his opinion on what is known, and he is expected to perform or practice what is known or what he thinks is good in the next process. ${ }^{7}$

Additionally, knowledge is generally 


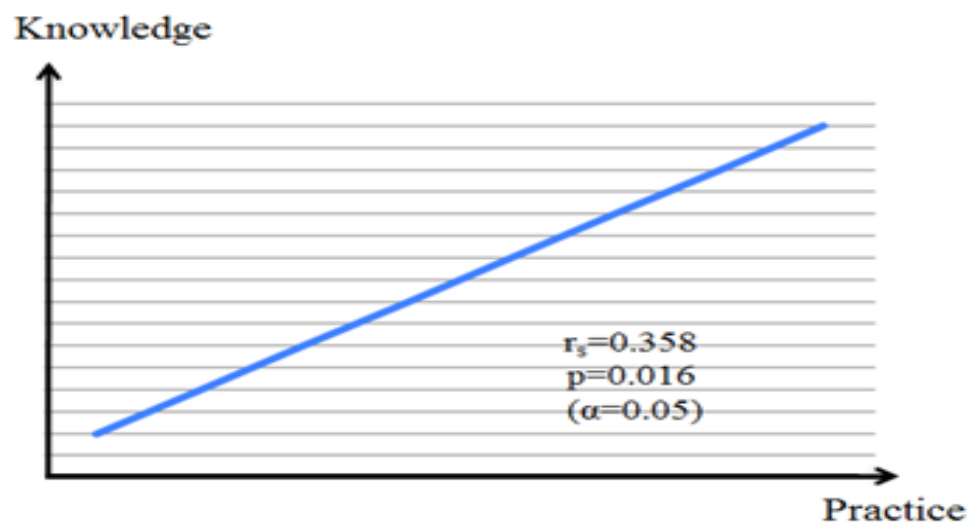

Figure 1 Correlation of Personal Hygiene Knowledge towards Personal Hygiene Practice

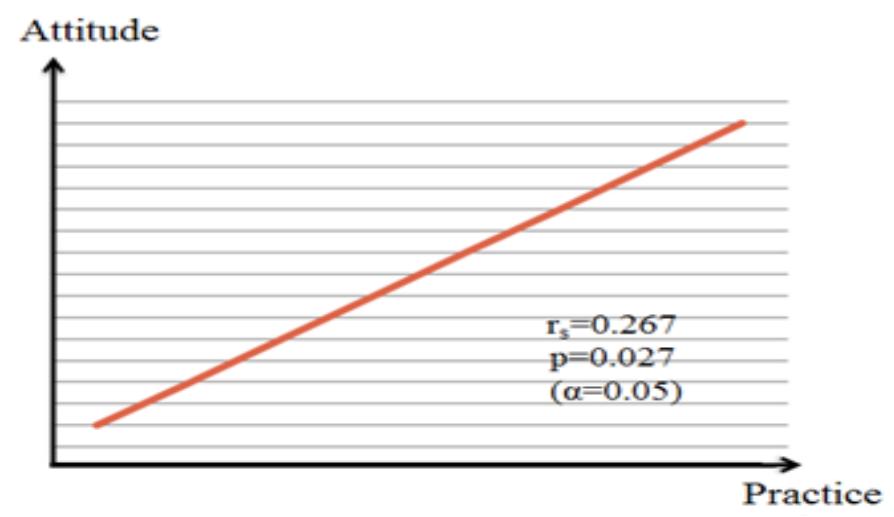

Figure 2 Correlation of Personal Hygiene Attitude towards Personal Hygiene Practice

obtained through the sense of sight (the eyes) and hearing (the ears) as well as experience. Students' knowledge about personal hygiene is not entirely obtained through formal education, but most of the information they learn is collected outside formal education facilities. Finally, information media may also provide the students with information to increase the level of their knowledge. These information media include public service advertisements, broadcast in television or other mass media. Access to knowledge on personal hygiene may also be gained from external behavior such as that of friends, parents, and society members. ${ }^{9}$ Besides, children's knowledge can be obtained both from internal and external sources. Internal knowledge is knowledge that comes from within based on life experience, while external knowledge is obtained from other people, including parents and teachers. Knowledge obtained from internal and external sources will add to children's knowledge on personal hygiene.

In terms of attitude, this study showed that almost all of the students had a positive attitude towards the importance of washing hands before eating (90.2\%). This result was similar to the study on Elementary School students in Bogota, Columbia ${ }^{10}$, which also indicated that most of the students show a positive attitude towards washing hands $(62.8 \%)$. This is likely because the attitude of those respondents is based on their 
knowledge as well as well-developed daily habits. One of the ways to shape and change attitude is through repetitive activities that will gradually be absorbed by individuals, such as the patterns used by parents to raise their children. The resulting behavior will affect the individual's behavior.

On the personal hygiene level, the majority of respondents were in a good category. This showed that most respondents had practiced decent knowledge and attitude of personal hygiene that they already had. According to Notoatmodjo ${ }^{7}$ behavioral development begins from the cognitive domain as the individual is already aware of stimuli in the form of objects, which then shapes their knowledge. Furthermore, the resulting knowledge will bring about mental responses in the form of the individual's attitude towards the objects they recognize. The resulting behavior will affect the individual's behavior.

Moreover, school children are at the best age to form their character. Elementary School children's ways of thinking develop gradually. Children are really in a learning stage. It starts from a family environment as the first environment for the children, especially their mother as the first educator. ${ }^{9}$ Besides the family, the school also brings systematic influence on shaping children's knowledge. Additionally, cchildren's memory are reaching the highest and strongest intensity. Their ability to memorize and remember things is at its peak. ${ }^{11}$ This fact can be used to deliver knowledge to elementary school children so that they can learn to apply personal hygiene and understand the consequences of not implementing personal hygiene in their daily lives, such as to suffer from diarrhea, acute upper respiratory tract infection (URTI), teeth and skin problems, and ascariasis.

Regarding the correlation of personal hygiene knowledge, attitude and practice, this study discovered that there was correlation between those variables, but the correlation was weak. Another study conducted by $\mathrm{Oyibo}^{5}$ in Abraka, Nigeria, reported that there is a significant relationship between knowledge and attitude regarding personal hygiene and its influence on practices of personal hygiene by elementary school students.

This study had limitations. It was difficult to value the personal hygiene practices using a questionnaire. Ideally, the data collection of personal hygiene practices should be performed by observation.

It can be concluded that the majority of students have the knowledge, attitude and practices of their personal hygiene. Thus, there is correlation between those variables, although the correlation is weak.

In order for children to practice personal hygiene in a good way, it is important to instill personal hygiene knowledge and attitude in the early age to avoid any hygiene-related diseases and have a good living in the future. Therefore, there is need for parents and teachers to maintain the values of personal hygiene in school children. Besides, the school has also an important role such as to include personal hygiene studies into the curriculum at school.

\section{References}

1. Kementerian Pemberdayaan Perempuan dan Perlindungan Anak, Badan Pusat Statistik Republik Indonesia. Profil anak tahun 2012. Jakarta: CV. Miftahur Rizky; 2012.

2. Andaruni A. Gambaran faktor-faktor penyebab infeksi cacingan pada anak di SDN 01 Pasirlangu, Cisarua. Jurnal Universitas Padjadjaran. 2012;1(1):1-14.

3. Hassan BAR. Importance of personal hygiene. Pharmaceut Anal Acta. 2010;3:e126.

4. Sheren NA, Kareem FA, Abdulla SA. Knowledge and attitudes of pupils in some of primary schools regarding personal hygiene in Erbil city. Kufa Journal for Nursing Sciences. 2012;2(1):1-9.

5. Oyibo PG, Basic personal hygiene: Knowledge and practices among school children aged 6-14 years in Abraka, Delta State. Continental J. Tropical Medicine. 2012;6(1):5-11.

6. Vivas AP, Gelaye B, Aboset N, Kumie A, Berhane Y, Williams MA. Knowledge, attitudes and practices (KAP) of hygiene among school children in Angolela, Ethiopia. J Prev Med Hyg. 2010;51(2):739.

7. Notoatmodjo S. Promosi kesehatan dan ilmu perilaku. Jakarta: Rineka Cipta; 2007.

8. Rosidi A, Erma H, Mita M. Hubungan kebiasaan cuci tangan dan sanitasi makanan dengan kejadian diare pada anak Sekolah Dasar Negeri Podo 2 Kecamatan Kedungwuni Kabupaten Pekalongan. J Kesehat Masy Indones. 2010;6(1):76-84.

9. Siswanto $\mathrm{H}$. Informal health education for early childhood in Indonesia. EDUCARE: International Journal for Educational Studies. 2009;1(2):219-32.

10. Lopez-Quintero C, Paul F, Neumark Y. Hand 
Briska Sudjana, Irvan Afriandi, Julistio T. B. Djais: Correlation of Personal Hygiene Knowledge, Attitude and 555 Practices among School Children in Sumedang, Indonesia

washing among school children in Bogota, Colombia. Am J Public Health. 2009; 14(1):94-101.
11. Kartono K. Psikologi anak. Bandung: Mandar Maju; 2007. 